\title{
Seasonal, geographical, and habitat effects on the diet of a recovering predator population: the European pine marten (Martes martes) in Ireland
}

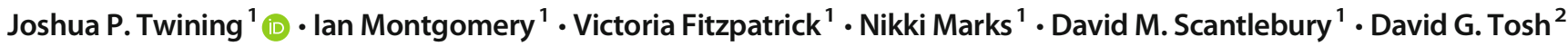

Received: 19 October 2018 / Revised: 18 April 2019 / Accepted: 8 May 2019 / Published online: 31 May 2019

(C) The Author(s) 2019

\begin{abstract}
Human activity is increasingly altering the natural world. Yet the natural adaptability of most mammal species remains unknown. Seasonal and spatial influences on the diet of temperate carnivores tending towards omnivory are, particularly, poorly understood. The pine marten is one such species which in Ireland and Britain is of additional interest due to the recent recovery in its range and abundance from near collapse. We investigated diet of the pine marten on regional, national, and continental scales and with regard to seasonal and habitat variation. Habitat effects on diet were examined with regard to samples from deciduous woodland, coniferous forestry plantations, heath-coniferous matrices, and mixed habitats. Finally, we discuss the implications of dietary variation in the ecological role of the European pine marten in Ireland and elsewhere and consider how these may be affected by further environmental change. The diet of the pine marten differed significantly amongst all studies across its range, although it maintains the same approximate trophic niche breadth throughout. This plasticity may explain its recovery in an environment where resources are scarce, and underscores its status as an opportunistic species which is likely to be robust to environmental and habitat changes in the future.
\end{abstract}

Keywords Pine marten $\cdot$ Diet $\cdot$ Scat analyses $\cdot$ Spatial effects $\cdot$ Seasonal variation $\cdot$ Habitat effects $\cdot$ Environmental resilience

\section{Introduction}

Anthropogenic processes are constantly, and increasingly, changing the "natural" world. Habitat destruction for the exploitation of resources and agricultural activity remain the greatest threats to global biodiversity (Maxwell et al. 2016).
A species' ability to adapt to this change is linked to characteristics that include trophic niche width (Williamson 1996; Vazquez 2006) and involve dietary plasticity (Vazquez 2006; Blackburn et al. 2009) and/or behavioural alterations (Sol et al. 2002). In contrast to species with a specialist niche, generalist predators may be more robust in terms of adaptation

Electronic supplementary material The online version of this article (https://doi.org/10.1007/s10344-019-1289-z) contains supplementary material, which is available to authorized users.

Joshua P. Twining

joshuaptwining@gmail.com

Ian Montgomery

i.montgomery@qub.ac.uk

Victoria Fitzpatrick

vfitzpatrick01@qub.ac.uk

Nikki Marks

n.marks@qub.ac.uk
David M. Scantlebury

m.scantlebury@qub.ac.uk

David G. Tosh

david.tosh@nmni.com

1 School of Biological Sciences, Queen's University, Belfast BT9 7BL, UK

2 National Museums Northern Ireland, Bangor Road, Holywood, Co. Down BT18 0EU, UK 
to change. Optimal foraging theory suggests that generalists exploit resources that maximise net energy intake whilst minimising energetic costs, switching diet to focus on highquality and abundant resources (Pyke et al. 1977). Such species may change diet opportunistically as a response to seasonal fluctuations in resources or drastic change in the distribution of resources on a landscape scale (Stapp \& Polis, 2003; Popa-Lissenu et al. 2007). Native predators support ecological processes that are integral to the developing structure of ecosystems. They can affect community composition and productivity, and, hence, can directly impact the wide range of ecosystem services associated with biodiversity (Taylor 1984; Arnundrud et al. 2015; Breviglieri and Romero 2017). Despite a growing body of research focusing on understanding the causes and consequences of inter-annual fluctuations in predation (O'Donoghue et al. 1998; Vucetich et al. 2011), our understanding of predation remains incomplete due to the paucity of data on seasonal, annual, and spatial variation in the diet of predators (Metz et al. 2012). In contrast to savannah ecosystems involving large specialist carnivores (Marker et al. 2003; Hayward and Kerley 2005; Hayward et al. 2006; OwenSmith 2008; Davidson et al. 2013), there are few detailed studies of generalist omnivorous carnivores. Those in temperate systems which undergo pronounced spatio-temporal variations in resource availability are particularly scarce. Perturbations in resource availability result from large-scale environmental and ecological processes such as annual cycles in the availability of fruit and seeds (Gregory \& Macdonald, 2009), and seasonal patterns in bird migration, nesting, and fledging (Walker et al. 2017). Identifying seasonal and habitat effects in foraging of temperate predators, and their ability to survive extreme seasonal fluctuations in trophic interactions, will enhance understanding of their potential to adapt to global environmental change in temperate ecosystems (Davies et al. 2011; Seabra et al. 2015).

The European pine marten (Martes martes) is a small, semi-arboreal mustelid typically associated with coniferous and deciduous habitats (Delibes 1983; Zalewski et al. 2004; Croose et al. 2016) but its use of heathland and other open habitats is increasingly being acknowledged in degraded landscapes (Caryl et al. 2012; Twining et al. In prep.). Pine martens are at the western edge of their global range in Britain and Ireland, where it is recovering from historical decline driven by land-use change and persecution (Langley and Yalden 1977; Birks 2002; Croose et al. 2014). Although anthropogenic processes were the primary drivers of pine marten decline, it is not clear how its habitat and trophic requirements are fulfilled on islands where perceived optimal habitat, e.g. woodland has declined since Neolithic times (Montgomery et al. 2014). The UK has some of the lowest forest cover in Europe, at $13 \%$ (Forestry Commission 2011) compared to the European Union average of $37 \%$ (Forestry Commission 2010). Northern Ireland has the lowest woodland cover, which in 2017, was $8 \%$ (Forestry Commission, 2017). Further, over $75 \%$ of Northern Ireland's forest cover is immature $(<30$ years old), commercial coniferous plantation predominantly comprised Sitka spruce (Picea sitchensis), Scots pine (Pinus sylvestris), and Norway spruce (Picea abies). Limited research exists on the ability of the pine marten to persist in such degraded and fragmented habitats created through deforestation and rotation cycles in commercial plantations (Caryl et al. 2012; O'Mahony et al. 2014). Thus, it is not clear how these habitat and landscape effects influence diet, interspecific interactions, and ecosystem functioning. However, it is clear that in spite of historical loss of preferred habitat, pine marten populations have persisted and expanded their range since the 1980s. This reversal is suspected to be due to a combination of factors that include the banning of a poison used in bait, strychnine, and protection under national (Wildlife and Countryside Act, 1981) and international law (EU Habitats Directive, 1992) (O'Sullivan 1983; O'Mahoney et al. 2017). One plausible explanation for the species' persistence and subsequent recovery is that it has a plastic trophic position in that it can deal with spatial and temporal changes in prey and food availability.

At present, knowledge of the species' diet supports this hypothesis as it is considered broad and varied in studies from across its range. However, in central and northern Europe, pine martens predate small mammals and specifically, vole species (Balharry 1993; Gurnell et al. 1994; Paterson and Skipper 2008; Putman 2000; Zalewski et al. 1995; Zalewski et al. 2004; Helldin 2000). Despite the wide variation in the occurrence of fruit and invertebrates in these studies, microtine rodents are consistently the most important prey of pine martens throughout their continental European range and Britain (Clevenger 1993; Jedrzejewski et al. 1993; Zalewski et al. 1995; Helldin 2000; Caryl, 2008). The primary microtine rodent predated varies across the pine marten's range with British populations having a preference for Microtus spp., whilst those in Europe focus on Myodes spp. (Lockie 1961; Balharry 1993; Gurnell et al. 1994; Putman 2000; Caryl et al. 2012). Previous research has shown in European populations that pine marten densities are positively correlated with temporal fluctuations in abundance of forest rodents (Zalewski \& Jedrzejewski, 2006). In contrast to Britain and mainland Europe (Montgomery et al. 2014), there are no native vole species present in Ireland, and small mammal biodiversity is less than in Britain and continental Europe. Although the bank vole (Myodes glareolus) is present throughout much of southern Ireland where it has been introduced (Montgomery et al. 2014), dietary preferences of pine marten in Ireland are likely still impacted, with reliance on resource groups other than small mammals, e.g. birds and carrion in winter and spring, or greater dependence on invertebrates and fruit in summer and autumn. Such plasticity may mean that martens fill a different trophic position in Ireland compared to the rest of 
their European range. Studies from Ireland are few and concentrate on small mammals which suggest a preference for wood mice (Apodemus sylvaticus), pygmy shrews (Sorex minutus), and, where they occur, invasive bank voles (Sheehy et al. 2013; O’Meara et al. 2014). To date, studies from Ireland have neglected the importance of other food groups, or concentrated on single study sites (Lynch and McCann 2007; Warner and O'Sullivan 1982) and fail to address how pine marten survived habitat loss and expanded their distribution.

There has been no large-scale investigation of pine marten diet in Ireland that addresses habitat and landscape effects as well as seasonal variation. Data pertaining to regional and seasonal effects on a diet in a temperate carnivore with omnivorous tendencies will be useful in understanding the ability of a small generalist species to recover in a degraded landscape. There is also no study comparing diet in pine marten on a continental scale. Thus, we investigate the diet of Pine marten with respect to the following: (a) regional, national, and continental scales; (b) seasonal variation; and (c) habitat effects. We discuss implications of dietary variation in the ecological role of the pine marten in Ireland and elsewhere in Europe and consider how these may be affected by future environmental change.

\section{Methodology}

\section{Scat surveys}

Twenty sites were chosen across the pine martens range in Northern Ireland based on an earlier survey using camera traps to examine the distribution of squirrel species and pine marten (Fig. 1, Table S1, Tosh 2015). In this study, Northern Ireland was split into $1 \mathrm{~km}^{2}$ hectads; each had a camera trap and baited feeder. Sites with pine marten occupancy were selected for scat surveys (Table S1). Sites were categorised into four habitat groups, namely; deciduous woodland $(n=5)$, mixed broadleaf and coniferous $(n=4)$, heath-coniferous matrix $(n=3)$, and coniferous plantation $(n=8)$ based on major tree species present. Coniferous plantations were typically made up of single stands of Sitka spruce (Picea sitchensis), Scots pine (Pinus sylvestris), or Norway spruce (Picea abies). Heath-coniferous matrices were dominated by open areas of heather (Calluna vulgaris), gorse (Ulex gallii), bilberry (Vaccinium myrtillus), and cowberry (Vaccinium vitis-idaea) with small stands of the former conifer species. Deciduous woodland was dominated by broadleaf species including oak (Quercus robur), beech (Fagus sylvatica), ash (Fraxinus excelsior), and hawthorn (Crataegus monogyna). Mixed forests were a combination of coniferous plantation and broadleaf woodland tree species (see Table S1).

Scats were collected along one 3-km transect in each location (Balharry 1993; Croose et al. 2014). Prior to sampling, each site was visited and all scats were cleared to ensure all future scats collected were fresh and deposited during that sampling month. Subsequent visits to each site were made once a month from December 2015-January 2017, for a total of 12 visits per site throughout the sampling year in addition to the visit for scat clearance. Due to previously observed error by certain individual recorders using a morphological approach to scat identification (Davison et al. 2002), every effort was taken to ensure correct species assignment and minimalise error. All scat surveys, identification, and analysis were performed by the lead author to remove recorder bias. Scat surveys were only conducted in locations with known occupancy of pine martens. Every scat collected was rated based on the following morphological and topographical factors: location, substrate deposited on, size, shape, colour, and smell. Pine marten scats are typically heart or C-shaped, with a pungent, aromatic smell (Lynch and McCann 2007; Birks 2017). Only fresh scats were collected; hence, smell and
Fig. 1 a Map showing Northern Ireland within the context of British Isles, b map showing twenty sampling sites across Northern Ireland, UK
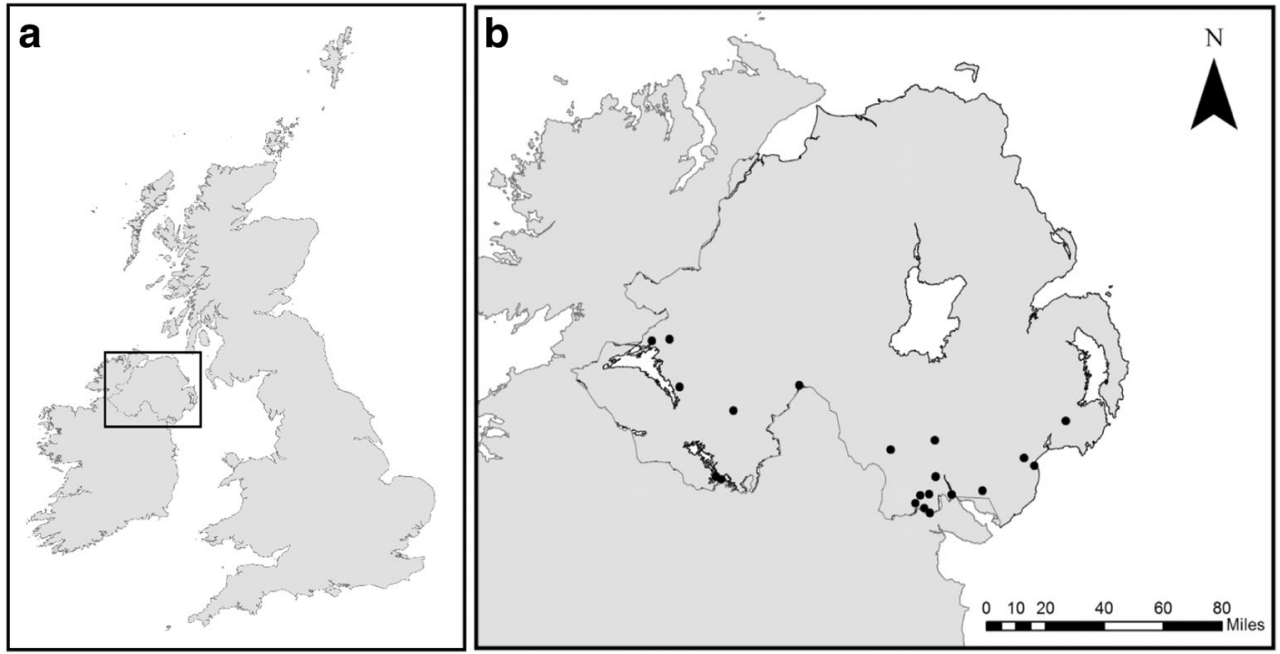
morphology of scat were the defining factors in assigning species to scats (Lynch and McCann 2007). All scats that did not meet all the criteria, or if there was any doubt in regard to species assignment, were discarded (>150 scats). Scats were stored in sealable bags with self-indicating silica gel as a desiccant for a minimum of 4 weeks until they were a constant mass (g). Dry macro-analysis of scats was conducted; dried scats were broken down and separated into their constituent parts using forceps. Mammal hairs were identified to species level (except lagomorphs, see below) through an examination of guard hair cuticle scales and medulla patterns at $\times 10$ and $\times 40$ magnification (Teerink, 1991; Cornally et al. 2016). Lagomorphs were not identified to species level due to the difficulty in differentiating species using cuticle and medulla hair fragments (Cornally et al. 2016). Carrion was identified by the presence of hair as above, or in the absence of hair, due to the presence of a black tar-like substance that results from consuming viscera of prey (Balharry 1993). Birds were identified to family level using barbule structure (Day, 1966) and invertebrates to family level using exoskeletal remains (Chinery 1993). Fruits were identified to species level using a reference collection of possible material assembled during and after field work.

Data are reported as the frequency of occurrence (FO\%) to make it comparable to previous dietary studies; $94 \%$ of published studies utilise FO\% with $50 \%$ using this as the sole method to report results of scat analysis (Klare et al. 2011). Frequency of occurrence was calculated as:

FO $\%=\frac{\text { Number of times prey item present }}{\text { Total number of scats }} \times 100$

However, as $\mathrm{FO} \%$ over-estimates the importance of small items (e.g. invertebrates, Klare et al. 2011), results are also reported using percentage biomass of hard remains (BP\%). This more quantitative approach is used less commonly but provides a more accurate approximation of true diet (Klare et al. 2011). The mass of the whole scat was recorded, and then the individual components were weighed. Percentage biomass was calculated as:

$\mathrm{BP} \%=\frac{\text { Mass }(\mathrm{g}) \text { of the individual food item }}{\text { Total mass }(\mathrm{g}) \text { of scat }} \times 100$

Dietary data were grouped into small mammals ( $1 \mathrm{~g}-1 \mathrm{~kg})$, carrion, birds, lagomorphs, invertebrates, and fruit. Pearson's chi squared $\left(\chi^{2}\right)$ and Fisher's exact tests (FET) were used to compare proportions of food groups in different seasons and habitats. Due to the simplicity of the statistical tests used and associated assumptions, a significance threshold of 0.02 was used as opposed to the conventional $P$ value of 0.05 to avoid false positives (Colquhoun 2017). The degree of specialisation of the diet was estimated based on Levin's standard index of niche breadth (B) that ranges from 0 to 1 (Levins 1968), so that values close to 1 indicate a generalist diet and those close to 0 indicate a specialised diet. Levin's niche breadth was calculated as:

$B=\frac{1}{\sum p_{i}^{2}}$

where $B$ is niche breadth, $p_{i}$ is the proportion of individuals found using resource $i$. In order to standardise niche breadth between 0 and 1 , the following calculation was used:

$B_{A}=1-\frac{B-1}{N-1}$

where $N$ is number of resources used by any population.

Dietary data collected in this survey were compared with similar data from throughout the pine marten's known European range. A literature search was conducted and comparable large datasets based on scat analysis in a discreet geographical area were selected for analyses. Pearson's chi squared was used to compare proportions of different dietary components in Ireland, in Britain and Ireland, and finally across the European range. Levin's standard index of niche breadth was calculated for all datasets, and Pearson's chi squared was used to compare the degree of specialisation. All statistical tests were carried out in R. 3.2.1 (R Core Team 2014).

\section{Results}

\section{Diet of European pine marten (Martes martes) in Northern Ireland}

A total of 918 pine marten scats were collected from 19 sites, with 57 plant, invertebrate, and vertebrate taxa represented in the macro-remains (Table 1). One site produced zero pine marten scats collectible for analysis. A small amount of plant material was unidentifiable $(0.013 \mathrm{BP} \%)$ and was excluded from the analysis. Figures $2 \mathrm{a}$ and $\mathrm{b}$ illustrate the presence of food categories by $\mathrm{FO} \%$ and $\mathrm{BP} \%$ respectively. Invertebrates were the most commonly occurring items in the faeces (Fig. 2a) but contributed little in terms of the biomass of hard remains (Fig. 2b). Invertebrate material consisted mainly of beetles (Coleoptera), bees and wasps (Hymenoptera), slugs and snails (Gastropoda), and earthworms (Oligochaeta). Fruit was also common (Fig. 2a), but unlike invertebrates, fruit formed a major part of the diet as quantified using biomass of hard remains (Fig. 2b). The fruit component was dominated by rowan (Sorbus aucuparia), blackberry (Rubus fruticosus), and bilberry (Vaccinium myrtillus), but hawthorn (Crataegus monogyna) and cherry (Prunus avium) were also 
Table 1 Summary of major prey and other food items by number of scats an item occurred in $(N)$, average frequency of occurrence (FO\%), and percentage biomass $(\mathrm{BP} \%)$ in scats over all sites and seasons $(n=19)$

\begin{tabular}{|c|c|c|c|c|}
\hline Group & Species & $N$ & $\mathrm{FO} \%$ & $\mathrm{BP} \%$ \\
\hline \multirow[t]{7}{*}{ Fruit } & Rowan (Sorbus aucuparia) & 282 & 30.34 & 33.30 \\
\hline & Blackberry (Rubus fruticosus) & 235 & 25.83 & 6.15 \\
\hline & Bilberry (Vaccinium myrtillus) & 67 & 7.29 & 2.50 \\
\hline & Hawthorne (Crataegus monogyna) & 12 & 1.32 & 0.88 \\
\hline & Cherry (Prunus avium) & 33 & 3.59 & 4.58 \\
\hline & Cotoneaster (Cotoneaster integerrimus) & 15 & 1.80 & 1.41 \\
\hline & Ivy (Hedera helix) & 2 & 0.22 & 0.04 \\
\hline \multirow[t]{6}{*}{ Small mammals } & Wood mouse (Apodemus sylvaticus) & 184 & 19.85 & 7.74 \\
\hline & Pygmy shrew (Sorex minutus) & 83 & 14.4 & 2.28 \\
\hline & House mouse (Mus musculus) & 39 & 5.27 & 1.77 \\
\hline & Brown rat (Rattus norvegicus) & 27 & 3.9 & 0.63 \\
\hline & Red squirrel (Sciurus vulgaris) & 37 & 4.20 & 1.35 \\
\hline & Grey squirrel (Sciurus carolinensis) & 11 & 3.00 & 0.84 \\
\hline Large mammals & Sheep (Ovis aries) & 49 & 5.56 & 4.67 \\
\hline \multirow[t]{4}{*}{ (Carrion) } & Red deer (Cervus elaphus) & 9 & 1.32 & 0.19 \\
\hline & Goat (Capra aegagrus hircus) & 10 & 1.05 & 0.33 \\
\hline & Fallow deer (Dama dama) & 7 & 0.65 & 0.31 \\
\hline & Unidentifiable & 36 & 4.03 & 6.38 \\
\hline Lagomorphs & Lagomorphs & 82 & 7.02 & 6.37 \\
\hline \multirow[t]{8}{*}{ Invertebrates } & Beetles (Coleoptera) & 415 & 54.5 & 2.29 \\
\hline & Wasps and bees (Hymenoptera) & 63 & 14.2 & 0.32 \\
\hline & Slugs and snails (Gastropoda) & 26 & 3.8 & 0.09 \\
\hline & Earthworms (Oligochaeta) & 18 & 2.27 & 0.001 \\
\hline & Damselflies (Zygoptera) & 1 & 0.16 & $<0.001$ \\
\hline & Millipedes (Diplopoda) & 4 & 0.51 & 0.002 \\
\hline & True flies (Diptera) & 11 & 1.81 & $<0.001$ \\
\hline & Spiders (Arachnida) & 1 & 0.16 & $<0.001$ \\
\hline \multirow[t]{7}{*}{ Birds } & Song birds (Passeriformes) & 147 & 20.41 & 8.368 \\
\hline & Doves and pigeons (Columbiformes) & 5 & 0.42 & 0.050 \\
\hline & Ducks and geese (Anseriformes) & 4 & 0.77 & 0.244 \\
\hline & Rails (Ralliformes) & 38 & 5.92 & 1.809 \\
\hline & Ground birds (Galliformes) & 3 & 0.72 & 0.017 \\
\hline & Falcons (Falconiformes) & 14 & 1.63 & 0.599 \\
\hline & Unidentifiable & 155 & 17.35 & 7.153 \\
\hline
\end{tabular}

present. Other items such as ivy (Hedera helix), cotoneaster (Cotoneaster integerrimus), and damson (Prunus insititia) were present but did not contribute greatly to overall pine marten diet as revealed by faecal analyses.

Overall, birds were the dominant vertebrate prey, with similar frequency of occurrence to fruit across the 12-month period (Fig. 2a). The majority of birds identified in the scats were Passeriformes, but Falconiformes, Columbiformes, Anseriformes, Ralliformes, and Galliformes were also present, albeit infrequently. A large number of bird feathers remained unidentified as barbules used in identification were broken down in the gut during digestion (Day, 1966; Lynch and McCann 2007). In terms of biomass, birds were the second most important overall prey/food items (Fig. 2b).
Small mammals formed a staple part of diet throughout the year (Fig. 2a), mainly consisting of wood mouse, followed distantly by a pygmy shrew. House mouse (Mus musculus), brown rat (Rattus norvegicus), red squirrel (Sciurus vulgaris), and grey squirrel (Sciurus carolinensis) were also recorded but relatively infrequently. Small mammals were the third largest contributor to faecal biomass (Fig. 2b).

Evidence of species presumed to have been scavenged in the diet consisted of domestic and wild ungulate species: sheep (Ovis aries), goat (Capra hircus), red deer (Cervus elaphus), and fallow deer (Dama dama). All sheep and goat detected were adults as distinguished from lambs by long coarse hairs, as opposed to shorter, finer hair which would be present in the juveniles of these species. Carrion was an 

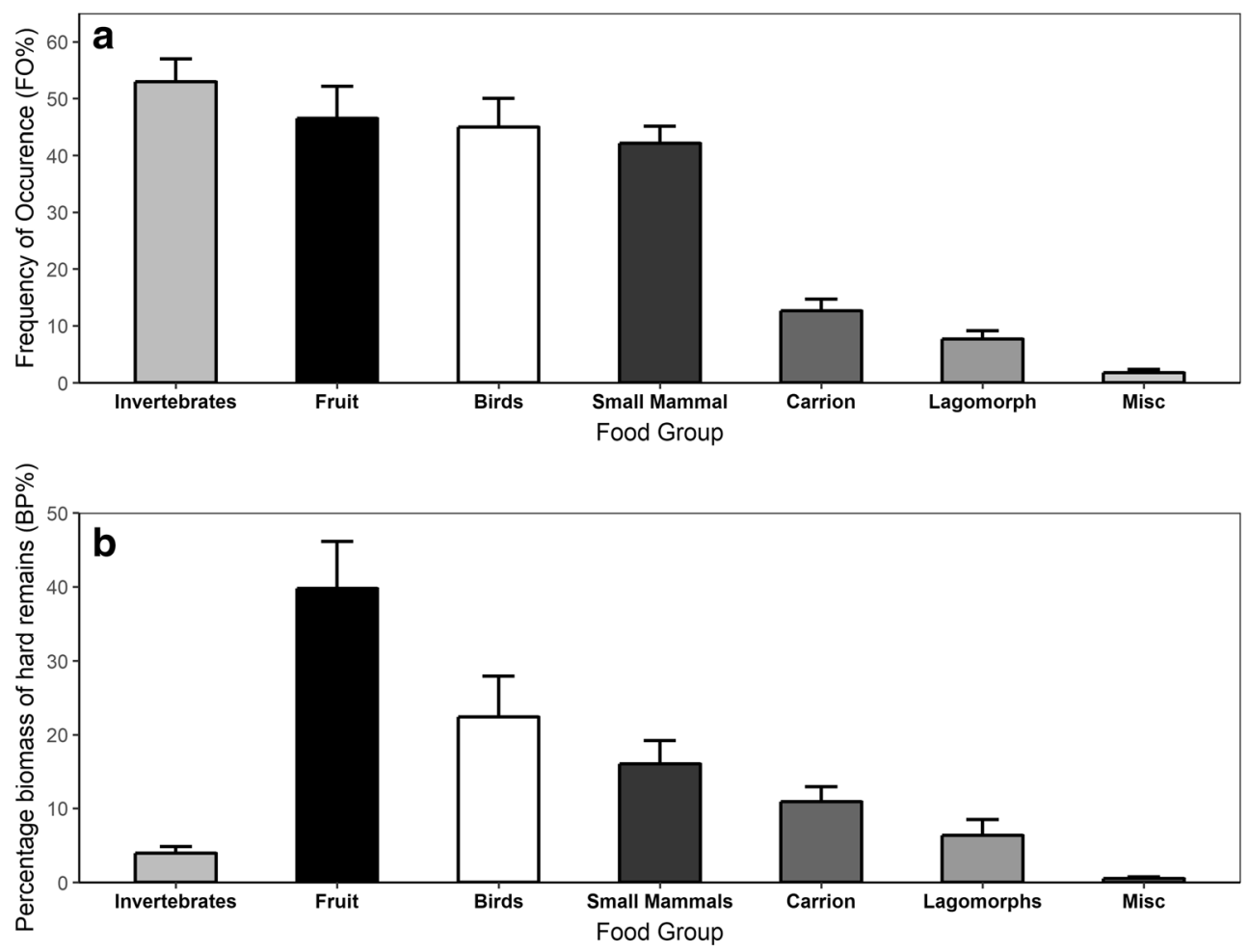

Fig. 2 Pine marten diet from 19 sites in Northern Ireland, with dietary components, split into taxa. a Mean per site (95\% clm) frequency of occurrence (FO\%) of items from scat analysis. b Mean per site $(95 \% \mathrm{clm})$ percentage biomass of hard remains $(\mathrm{BP} \%)$ of items from scat analysis

important food group in terms of biomass (Fig. 2b). Lagomorphs were recorded less commonly in scats than small mammals (Fig. 2a). This food group was made up of rabbits (Oryctolagus cuniculus) and hares (Lepus spp.). Lagomorphs comprised over $6 \%$ of faecal biomass (Fig. 2b). Miscellaneous faecal remains consisted of common frog (Rana temporaria), human refuse, and bird eggs which were collectively uncommon and unimportant dietary items in terms of contribution to overall hard biomass of scats (Fig. 2a and b).

\section{Seasonal dietary variation}

There was seasonal variation in the occurrence and biomass of food types, affecting all main categories of prey/food items. In spring, small mammals (Fig. 3a and b) occurred most frequently followed by birds, invertebrates, and fruit. In contrast, during the summer, invertebrates were the most common items in faeces and birds; small mammals and fruit had similar frequencies to each other. Fruit was the most frequent item in autumn and there was a marked decrease in the occurrence of the other food groups $\left(\chi^{2}, X_{2}=85.167, P=<0.001\right)$. During winter, small mammals and birds occurred most frequently whilst the presence of fruit decreased. Carrion occurrence in faeces peaked in spring and winter compared to summer, and, in particular, autumn (Fig. 3a and b).
Although birds were important in all seasons, peaks occurred in spring and summer. Fruit occurred in all seasons but was significantly higher in autumn than all other seasons (FET, $P<0.001$ ), and fruit also occurred significantly more in summer than spring (FET, $P=0.004$ ) or winter (FET, $P<0.001)$. Occurrence of fruit was not significantly different between spring and winter (FET, $P=0.374$ ). Frequency of bird remains in scats demonstrated seasonal peaks in spring and summer in comparison to other seasons (FET $=P=<$ 0.001 ), but was not significantly different between spring and summer ( $\mathrm{FET}=P=0.772$ ). Although winter had a higher average occurrence of birds than autumn, occurrence was highly variable but not significantly so (FET, $P=0.091$ ). Small mammal occurrence fluctuated throughout the year with a pronounced autumnal decrease. Small mammals occurred significantly less in scats in autumn than all other seasons (FET, $P=<0.001,<0.001,0.02$ ). Small mammals occurred significantly more frequently in spring than winter (FET, $P=0.006$ ) and summer (FET, $P=<0.001$ ). Occurrence of small mammals did not differ significantly between summer and winter (FET, $P=0.116$ ). Carrion frequency occurrence showed seasonal peaks in spring and winter in comparison to other seasons (FET, $P=<0.001$ ), but there was no significant difference between spring and winter (FET, $P=1$ ). There was a significant decrease in carrion occurrence observed from summer to autumn (FET, $P=0.02$ ). 

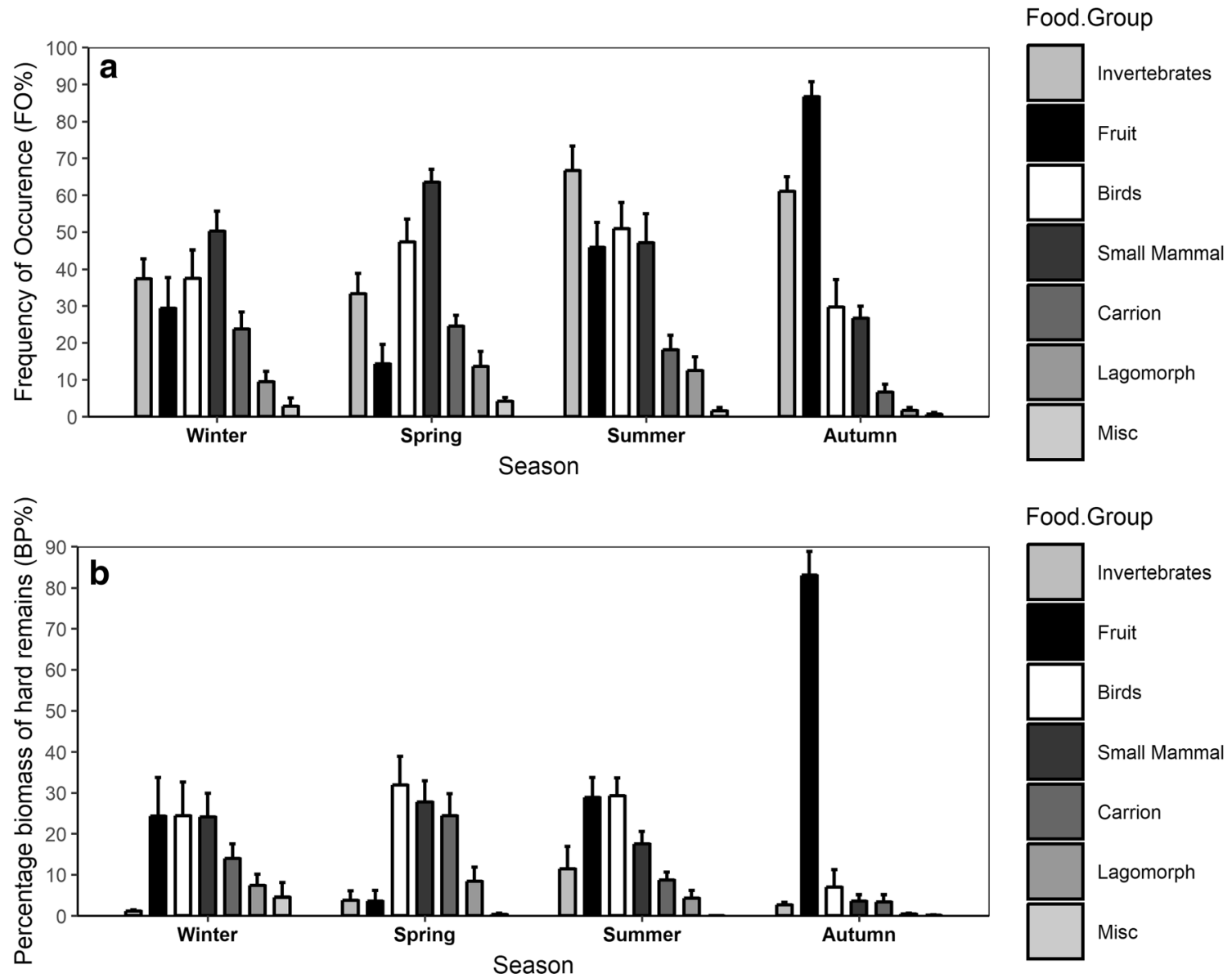

Fig. 3 Seasonal variation in pine marten diet throughout the year at 19 sites across Northern Ireland. a Mean per site ( $95 \%$ clm) frequency of occurrence from scat analysis of different food groups. b Mean $(95 \% \mathrm{clm})$ percentage biomass of hard remains in scats of different food groups

\section{Influence of habitat on diet}

In heath-coniferous matrices, the principal food source in scats was fruit (Fig. 4a and b) with a lower occurrence of birds and small mammals. The same pattern was observed in mixed woodlands, with fruit forming the most frequently occurring component, with a reduced occurrence of birds and small mammals. In coniferous plantations, pine marten diet as inferred by the presence in scats was dominated by birds and small mammals, followed by fruit. Although invertebrates were the most frequently occurring item, they are not considered to be dominant due to low biomass contribution. In deciduous woodland, diet was largely made up of birds, followed by small mammals. Fruit consumption was significantly higher in mixed forest, and heath-coniferous matrices in comparison to coniferous plantation (FET, $P=<0.001$ ), and deciduous woodland (FET, $P=<0.001$ ) but did not differ significantly between the former two habitats. Birds occurred in the diet significantly more frequently in deciduous woodland than all other habitat types (FET $=<0.001$ ). Carrion occurrence and biomass in scats did not vary significantly with habitat. Small mammal occurrence was not significantly different between heath-coniferous matrices, coniferous plantation, and deciduous woodland (FET, $P=0.125$ ), but was significantly lower in mixed forests (FET, $P=0.02$ ).

\section{Niche breadth}

Levin's standardised niche breadth of the European pine marten in Northern Ireland is $B=0.69$. Variation in niche breadth of pine martens across different habitats and seasons displayed variation (see Figs. 5 and 6) but not significantly: season ANOVA, $F_{1,20}=2.148, P=0.074$, and habitat ANOVA, $F_{1,20}=1.634, P=0.224$.

\section{European analysis}

Pine marten diet composition (i.e. occurrence of different food groups) was significantly different between every population studied across Europe (Table 2): Irish populations $\left(\chi^{2}, \mathrm{df}=6, X_{1,20}=122.26, P=<0.001\right)$; British Isles populations $\left(\chi^{2}, \mathrm{df}=12, X_{1,20}=517.02, P=<0.001\right)$, and Europe $\left(\chi^{2}, \mathrm{df}=30, X_{1,20}=1679.3, P=<0.001\right)$. Poland had the highest occurrence of small mammals and carrion. 

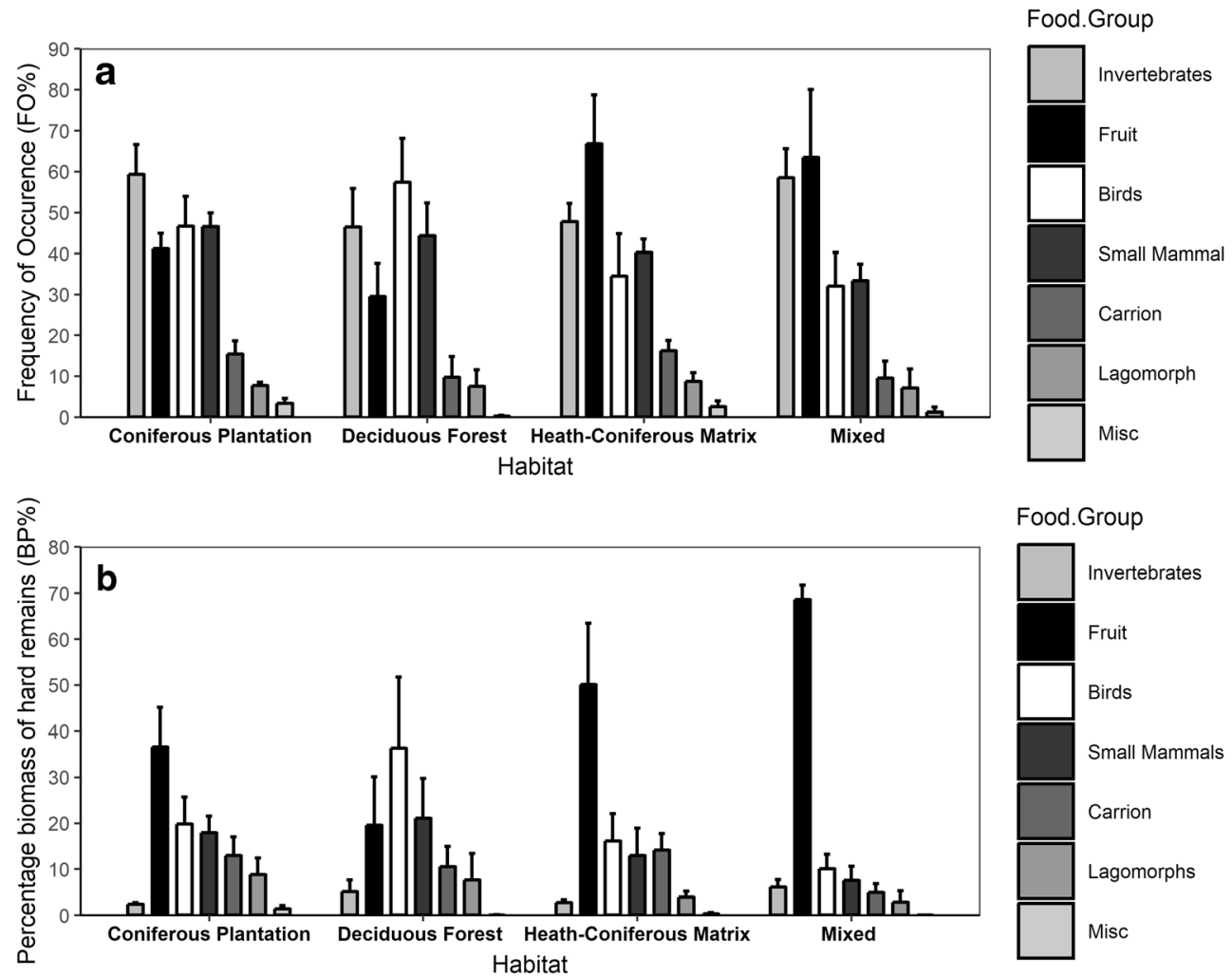

Fig. 4 Habitat variation in pine marten diet at 19 sites in Northern Ireland. a Mean per site $(95 \% \mathrm{clm})$ frequency of occurrence of different food groups from scat analysis. b Mean per site $(95 \% \mathrm{clm})$ biomass of hard remains in scats

Northern Ireland had the highest occurrence of birds and invertebrates. Invertebrates were also high in both Ireland and Poland, whilst fruit dominated in Ireland, Northern Ireland, and Italy (Table 2). However, despite this variation in the occurrence of food categories amongst studies, Levin's niche breadth was similar across all studies varying between 0.6 and 0.8 (Fig. 7, $\chi^{2}, X_{1,20}=0.043, P=1$ ). There were no continental, latitudinal, or longitudinal effects on niche breadth.

\section{Discussion}

This investigation demonstrates dietary plasticity in a temperate, generalist predator recovering from the historic impact of habitat loss and persecution (Langley and Yalden 1977; Birks 2017). The results suggest that generalist, omnivorous carnivores may be able to thrive even where optimal habitat and preferred prey are scarce. Diet varied substantially throughout the year and in different habitat types for the European pine marten in Northern Ireland. These differences are likely driven by changes in availability and vulnerability (i.e. presence of altricial juveniles) of resources and prey (Barber-Meyer et al. 2008; Metz et al. 2012) and energetic trade-offs resulting in resources being targeted when in their highest abundance. The ability to recover in an environment where optimal habitat is scarce and there are fewer prey species, as in Ireland (Table 3; Montgomery et al. 2014) suggests that pine marten populations may be relatively robust and able to survive further environmental change.

The present results concur with earlier studies throughout the European range of the pine marten, in indicating that it is an opportunistic, generalist predator. However, unlike southern Ireland, most studies indicate that small mammals are the most important dietary component in terms of frequency of occurrence and percentage biomass (Balharry 1993; Jedrzejewski et al. 1993; Helldin 2000; Zalweski et al. Zalewski et al. 2004). Typically, European martens make only limited, seasonal use of fruits, birds and other items. In this investigation, we identified an alternative pattern of resource use, with fruit, such as rowan and blackberry, and birds, predominantly passerines, the most frequently occurring, and prevalent in terms of percentage biomass in the pine marten diet as inferred from scats. Pine marten diet in Northern Ireland was highly variable, but almost two-thirds of total biomass was composed of three items; rowan (mountain ash) berries, song birds, and wood mice. Peaks in two of the most important prey groups (birds and fruit) coincided with likely peaks in their abundance (e.g. fruit in autumn) or the presence of vulnerable juveniles (e.g. young birds in early summer), whilst the most common small rodent, the wood mouse, was a staple component throughout the year. The 


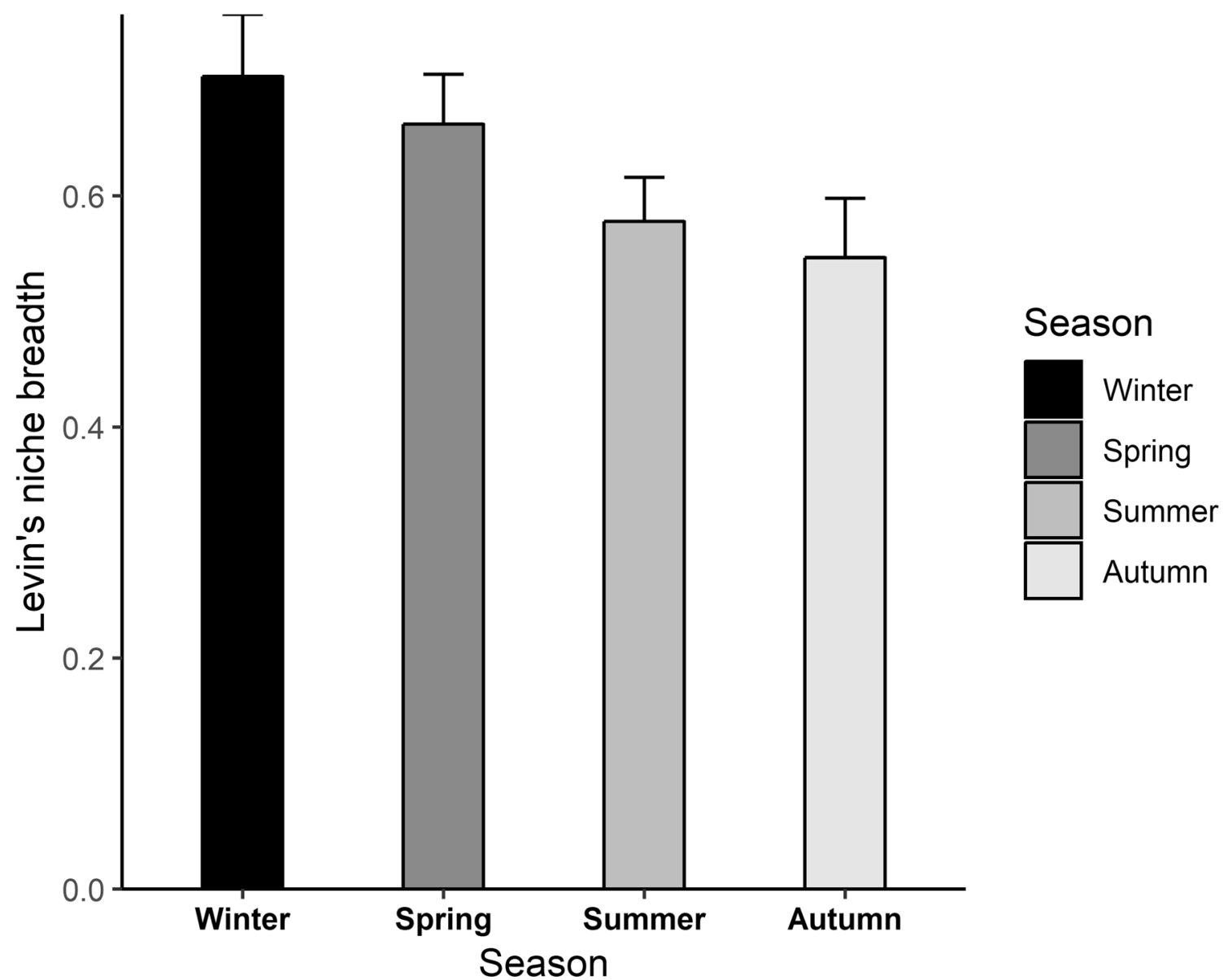

Fig. 5 Mean $(95 \%$ clm) Levin's standardised niche breadth of European pine marten throughout the year in seasons. Based on scat data from 19 sites across Northern Ireland

yellow-throated marten (Martes flavigula) in China, which also relies on small mammals as a staple resource, also has a preference for fruit when available (Zhou et al. 2011). These apparent dietary switches do not appear to be explained by fluctuations in the abundance of principal prey species, small mammals, but rather by the ease of procurement of fruit in fruiting season, or additionally, as in our study, birds during fledging. The pine marten diet, therefore, does not simply reflect the abundance of a single resource but is likely a function of abundance as well as the availability of alternate resources.

Niche breadth in Northern Ireland is indicative of a generalist species which specialises or has a preference for certain ephemeral species supplemented by a wide range of prey items suggesting a highly opportunistic predator. Despite major differences in the species present in the diet of the pine marten across its European range, its niche breadth remained very similar (ca $0.6-0.8$ ) between populations. This suggests that martens remain opportunistic predators feeding at multiple trophic levels regardless of geography, habitat, and species richness of prey communities Table 3 ).

The present results support the idea, that unlike elsewhere in its distribution, fruit is an integral food group for pine marten in
Ireland (Fairley 1970; Warner and O'Sullivan 1982; Lynch and McCann 2007). The relative importance of birds and small mammals, as observed in this study, was also evident in the 1980s in the west of Ireland (Warner and O'Sullivan 1982). However, the relative importance of birds and small mammals was reversed in the south-west (Killarney National Park; Lynch and McCann 2007), with small mammals being the most common item after fruit. Caution must be taken when comparing current results from a landscape or regional scale investigation with studies that concentrated at a single study site. Nevertheless, Irish studies contrast to Britain where $>80 \%$ of prey items in scats were field voles (Microtus agrestis) (Balharry 1993) and mainland Europe, where Myodes voles are dominant (Helldin 2000; Zalewski et al. 2004). This difference is likely a result of the reduced small mammal assemblage in Ireland compared to the rest of Europe (Table 3; Tosh et al. 2011). However, the characteristic Irish prey may change as the range of the introduced bank vole (Myodes glareolus; Claassens and O'Gorman 1965) and greater whitetoothed shrew (Crocidura russula; Tosh et al. 2008) increases in Ireland. Precedence for this exists already in Ireland where studies of predatory birds indicate shifts in dietary preferences. Where the range of the barn owl (Tyto alba) in Ireland overlaps 

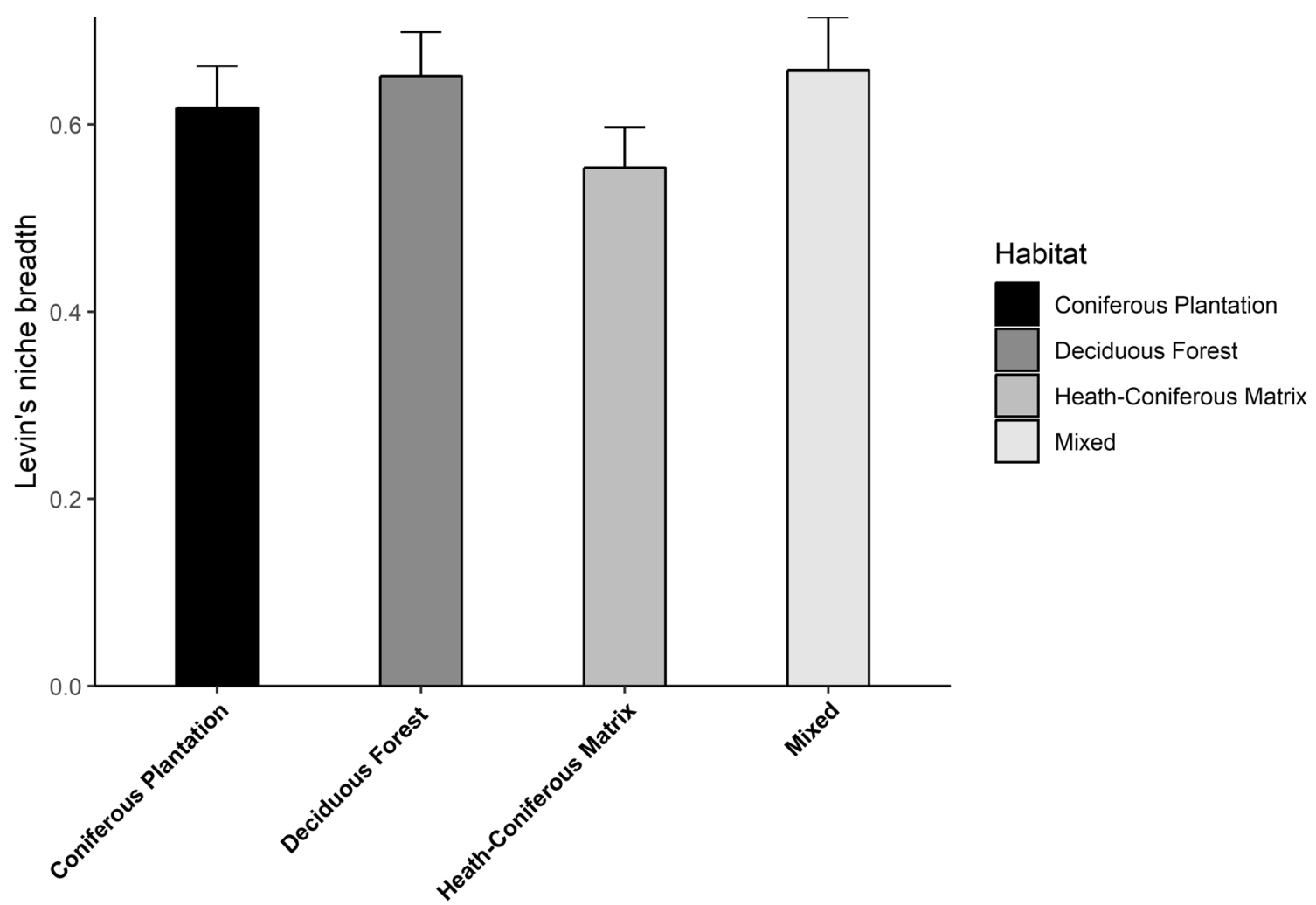

Habitat

Fig. 6 Mean (95\% clm) Levin's standardised niche breadth of European pine marten across various habitat types. Based on scat data from 19 sites across Northern Ireland

with that of the two recently introduced species, it shows a preference for the greater white-toothed shrew and bank vole over native species (Smiddy 2018a). Additionally, the kestrel (Falco tinnunculus) shows a similar trend where its range overlaps with the invasive bank vole, its diet becomes dominated by the species, occurring in up to $78 \%$ of pellets (Smiddy 2018b). The implications of such a dietary shift are currently unknown but could have implications for breeding success and population size. The bank vole is already a common prey item in pine marten scats where both occur in southern Ireland (Lynch and McCann 2007).

Fruit occurrence in scats varied significantly with season as observed previously in Ireland and throughout the species range. Similar seasonal patterns involving particular species of berry being consumed are usually the most abundant at the sites where investigations were carried out (Marchesi and Mermod 1989; Lynch and McCann 2007). Predators are thought to function at near maximum power outputs (Scantlebury et al. 2014) where fruit consumption may serve as a trade-off to conserve energy that would be otherwise wasted pursuing, and potentially failing to catch active prey species. Such patterns of resource use with high exploitation of fruit when available have been observed in other opportunistic omnivores such as brown bears (Ursus arctos) in Sweden (Stenset et al. 2016). There are many fruit-bearing species throughout Northern Ireland, but pine martens concentrated primarily on three: rowan, blackberry, and bilberry, as have been found in other studies throughout their European range (Balharry 1993; Helldin 2000; Caryl et al.

Table 2 Geographic variation in pine marten diet throughout the range in Europe from previously published datasets, results are presented in the frequency of occurrence $(\mathrm{FO} \%)$

\begin{tabular}{|c|c|c|c|c|c|c|c|}
\hline Country/author/sample size $(n)$ & Carrion & Small mammals & Birds & Invertebrates & Fruit & Lagomorphs & Other \\
\hline Scotland (Caryl et al. 2012); $n=2449$ & 3 & 30.5 & 18.2 & 16.8 & 33.1 & 0 & 0 \\
\hline Ireland (Lynch and McCann 2007); $n=387$ & 7.82 & 12.45 & 8.95 & 29.22 & 30.01 & 0.45 & 8.49 \\
\hline Sweden (Helldin 2000); $n=760$ & 4.8 & 38.8 & 10.9 & 10.6 & 15 & 5.3 & 5.8 \\
\hline Italy (Balestrieri et al. 2011); $n=109$ & 2.7 & 31.2 & 22.9 & 5.5 & 41.3 & 7.6 & 0 \\
\hline Poland (Zalewski et al. 2004); $n=1203$ & 17.38 & 58.7 & 33.9 & 30.35 & 5.15 & $\mathrm{~N} / \mathrm{A}$ & 24.1 \\
\hline Northern Ireland $n=918$ & 12.61 & 43.6 & 46.7 & 54.5 & 47.2 & 7.65 & 3.2 \\
\hline
\end{tabular}




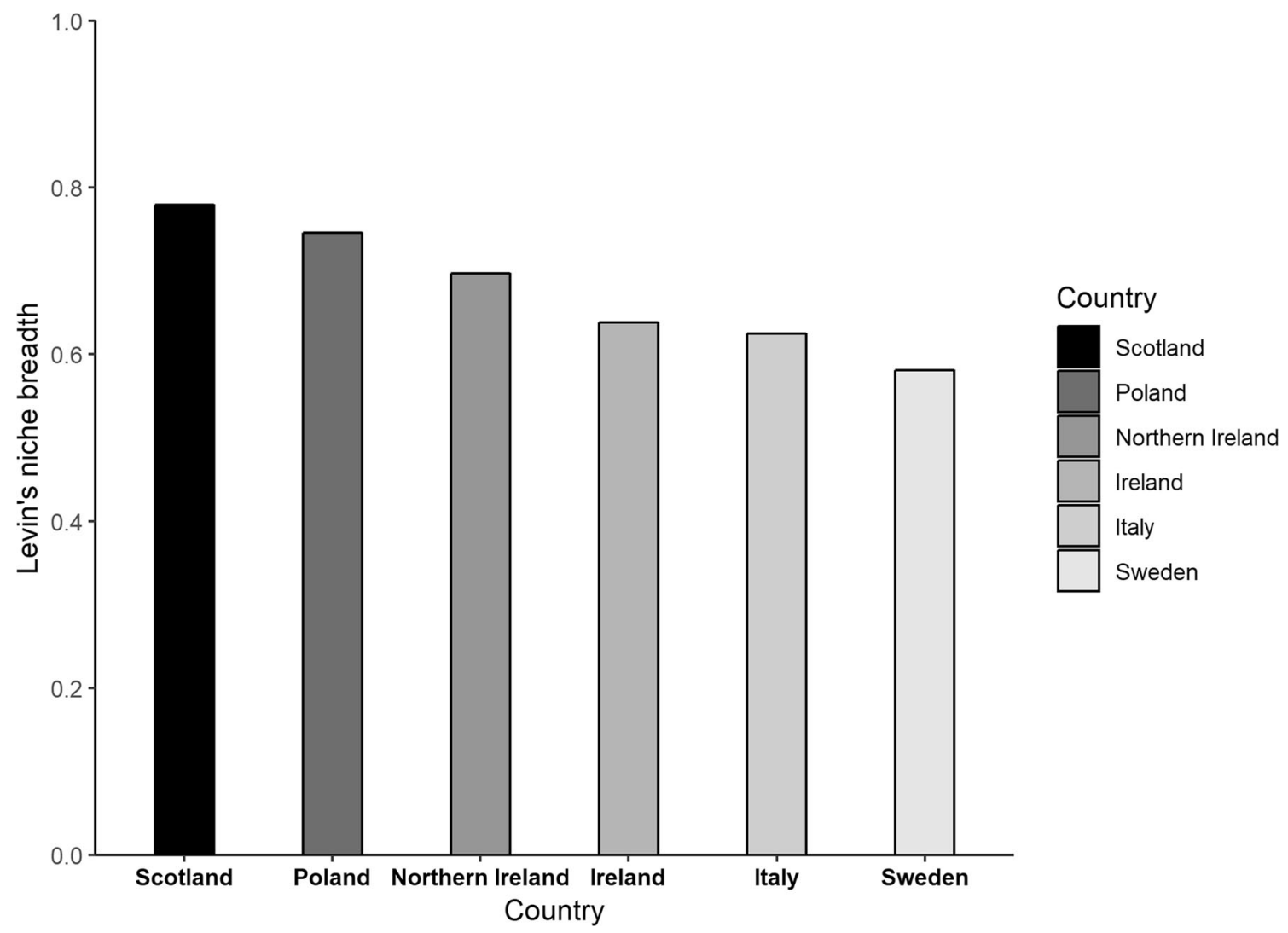

Fig. 7 Levin's standardised niche breadth of European pine marten across European range. Based on scat data from 19 sites across Northern Ireland and previously published data for other locations

2012). All three were key food items throughout summer and autumn, as previously demonstrated for blackberry (Fairley 1970; Lynch and McCann 2007), bilberry, and rowan (Helldin 2000; Caryl et al. 2012). The higher occurrence of rowan reported in this investigation as compared to other locations may reflect rowan being highly prevalent in upland Northern Ireland, along plantation edges and field boundaries (Rivers \& Beech, 2017), providing further evidence that martens feed primarily on items that are abundant and easily accessible in the environment.

Under seasonal and habitat conditions when fruit is less readily available, pine martens switch to alternative prey sources, primarily birds and small mammals. High predation of birds has also been observed in southern Ireland and Majorca where birds contributed to about $20 \%$ of overall biomass of faeces (Warner and O'Sullivan 1982; Clevenger 1993). The present investigation supports the majority of studies on pine marten diet that demonstrate seasonal peaks in avian prey primarily composed of passerines in spring and summer, when altricial, and thus vulnerable, juveniles and fledglings are present at or close to nests (Goszczynski, 1976; Marchesi and Mermod 1989; Balharry 1993; Jedrzejewski et al. 1993; Helldin 2000; Zalewski et al. 2004; Lynch and McCann 2007). Predation pressure from pine martens constrains nest characteristics of cavity-nesting birds (Kalinski et al. 2014). The present results suggest that generalist arboreal predators like pine martens have a potential role in limiting population recruitment in birds where small mammal abundance is low. Pine martens, thus, make a distinct shift in foraging ecology from a largely carnivorous ecology in
Table 3 The percentage forest cover (EU Forestry Commission 2018) and number of prey species of small mammals (Wilson et al. 2017, 2018) and birds (Dickinson and Remsen 2013) present throughout the range of the European pine marten

\begin{tabular}{lcclc}
\hline & No. rodent Sp & No. shrew sp & No. bird sp & Forest cover (\%) \\
\hline Ireland & 4 & 2 & 493 & 8 \\
Britain & 15 & 5 & 623 & 13 \\
Italy & 24 & 13 & 553 & 31 \\
Sweden & 18 & 6 & 529 & 57 \\
Poland & 30 & 8 & 462 & 30 \\
Northern Ireland & 3 & 1 & 354 & 8 \\
\hline
\end{tabular}


spring to primarily frugivorous life history in autumn. Switching to alternative prey is well documented in apex predators (e.g. Pole et al. 2004; Owen-Smith 2008). However, the present results provide an example of prey switching in a temperate mesocarnivore. This dietary plasticity and adapt ability may explain how pine martens populations have been able to recover in Ireland, from low density, isolated populations despite the paucity of woodland and commercial forestry (O'Mahoney et al. 2017).

The rates of occurrence and biomass of carrion in the diet in the present study were similar to studies from mainland Europe and Scandanavia (Jedrzejewski et al. 1993; Helldin 2000; Zalewski et al. 2004), further evidence of the propensity to feed on high energetic value, yet high-risk resources when present. Carrion occurred more often in scats of martens in coniferous plantation sites in comparison to deciduous or mixed forest sites perhaps as a result of increased prevalence of carrion in the environment where habitat is less diverse as in conifer plantations (Benbow et al. 2016), or, alternatively, because upland coniferous plantation is often adjacent to in-by-land and rough grazing fields. Carrion consumption also had seasonal peaks in spring and winter, unlike other studies which report a single peak of carrion consumption in winter coinciding with the increased death rate in ungulates (Jedrzejewski et al. 1993; Zalewski et al. 2004). The spring peak may result from the continuation of winter weather but is not necessarily representative of the continued prevalence of carrion. Instead, it may reflect the increased energetic demands of female pine martens provisioning for kits during this time. Thus, in spring, female pine martens may be driven to increase intake of high-value, high-risk resources, risking competition over carcasses with conspecifics and intraguild predators such as the red fox (Vulpes vulpes) which may otherwise be avoided. The high proportion of carrion in spring may also be evidence of food caching in pine martens (Pulliainen 1981; Helldin 2000; Twining et al. 2018). Nevertheless, pine martens are important scavengers in Northern Ireland and elsewhere, and thus provide a key ecosystem process with implications for nutrient recycling and disease dynamics (Wilson and Wolkovich 2011; Twining et al. 2017).

Despite invertebrates being the most frequently occurring items in pine marten scats, they are often thought to contribute little to the diet as percentage biomass is typically small, as was observed here. This leads to invertebrates being largely discarded as an unimportant food item despite being extremely commonly occurring (Balharry 1993; Helldin 2000; Lynch and McCann 2007). However, this may be a reflection of inherent biases of determining diet from scat analysis based on hard remains, rather than an accurate representation of diet owing to the digestibility of invertebrates in comparison to other items, a potentially erroneous conclusion. Such nebulous interpretations demonstrate the need for accurate quantitative ingested prey weight transformations, only possible through feeding trails (Balharry 1993). The ubiquitously high occurrence of invertebrates across all seasons and habitats may suggest that invertebrates are an essential resource for pine martens. There were seasonal peaks in invertebrate consumption in autumn and summer alongside increased consumption in fruit, which may suggest that invertebrates, specifically beetles, serve as a key protein source for martens when assuming an otherwise frugivorous foraging pattern. This pattern of invertebrate use was observed in most (Warner and O'Sullivan 1982; Marchesi and Mermod 1989; Balharry 1993) but not all (Ni Neachtain 1998; Lynch and McCann 2007) previous studies of pine marten diet. Invertebrate consumption was consistent across all habitat types and was dominated by beetles, followed by common wasps and honey bees, and then slugs and snails. Other studies report beetles as the dominant invertebrates consumed (Warner and O'Sullivan 1982; Balharry 1993; Helldin 2000; Lynch and McCann 2007). Remains of beetles in scats in this study were typically large ground beetles and dung beetles, as in Sweden (Helldin 2000). As beetles were a highly abundant prey species but do not significantly contribute to biomass of scats, it has been suggested that pine martens consume beetles when opportunistically encountered whilst searching for other items. Hymenoptera have also been reported in pine marten diet previously (Marchesi and Mermod 1989; Balharry 1993; Helldin 2000; Lynch and McCann 2007). Their seasonal peaks in spring and winter suggest predation of old nests or those displaying sluggish emergence. Bees and wasps were less common in scats from open heath suggesting reduced availability of nests, again indicating the opportunistic nature of pine martens. Although the hard biomass of Hymenoptera in scats was low, their presence may indicate that martens target nests for honey and larvae (Marchesi and Mermod 1989) and energy-rich food resources which leave minimal hard remains in scats, and are thus underestimated in diet as a whole. This provides further evidence for the need for quantitative biomass-based correction values (as opposed to the frequency of occurrence-based correction values presented in Lockie 1961; Balharry 1993) to estimate ingested prey weight for more accurate estimation of diet.

Previously noted difficulties in distinguishing pine marten scats morphologically from other species have been highlighted in Britain where there are numerous similar sized predators (Davison et al. 2002). Recent advancement of real-time PCR methods for genetically determining species of scats using mitochondrial DNA (O'Reilly et al. 2007) has resulted in certain researchers investigating marten diet to adopt this method (Caryl et al. 2012). However, the high failure rate and high cost of such genetic techniques prohibit many large-scale studies from adopting such an approach. In this paper, we used a multi-evidence approach, firstly confirming the presence of pine martens at sites using camera traps, followed by a single experienced fieldworker, conducting scat surveys using a 
strict scoring system with specific criteria (i.e. pungent aromatic smell, C- or heart-shaped morphology) on fresh scats only, discarding all scats that were in doubt. It would be pertinent for a future study to compare these methods in the context of dietary investigation, as it could save researchers' valuable time and resources.

The omnivorous trophic position of the pine marten is evident throughout Europe, where it is heavily reliant on a limited set of prey species, supplemented by a wide range of ephemeral resources. The large variety of plant and animal species that martens exploit demonstrate their importance in providing key ecosystems services, affecting plant communities as well as vertebrate populations. They are critical in seed dispersal of various fruiting species and the removal of carrion from the environment as well as management of species of conservation interest such as the red squirrel (Sheehy and Lawton 2014; Sheehy et al. 2018). The extent to which the pine marten is involved in these processes is dependent on the resources available, whether they are highly abundant or scarce. Prey switching and dietary plasticity not only provide an explanation for the recovery of pine marten populations in Ireland despite a lack of woodland and forest but also suggest that they may be robust to future environmental changes. Key survival mechanisms in carnivores dealing with fluctuating resources have been documented previously in apex predators. The present report indicates that these behavioural traits are also apparent in a temperate, generalist mesocarnivore.

Acknowledgements We would like to thank an anonymous referee who made constructive comments to help us improve the manuscript.

Funding information This project received funding from the People's Trust of Endangered Species and a studentship from the Department for the Economy, Northern Ireland.

Open Access This article is distributed under the terms of the Creative Commons Attribution 4.0 International License (http:// creativecommons.org/licenses/by/4.0/), which permits unrestricted use, distribution, and reproduction in any medium, provided you give appropriate credit to the original author(s) and the source, provide a link to the Creative Commons license, and indicate if changes were made.

\section{References}

Arnundrud SL, Srivastava DS, O'Connor MI (2015) Indirect effects of predators control herbivore richness and abundance in a benthic eelgrass (Zostera marina) mesograzer community. J Anim Ecol 84:1092-1102

Balestrieri A, Remonti L, Prigioni C (2011) Assessing carnivore diet by faecal samples and stomach contents: a case study with Alpine red foxes. Cent Eur J Biol 6:283-292

Balharry, D. (1993). Factors affecting the distribution and population density of Pine Martens (Martes martes) in Scotland. A thesis submitted for the degree of $\mathrm{Ph}$. D at the University of Aberdeen, Scotland
Barber-Meyer SM, Mech LD, White PJ (2008) Elk calf survival and mortality following wolf restoration to Yellowstone National Park. Wildl Monogr 169:1-30

Benbow ME, Tomberlin JK, Tarone AM (2016) Introduction to carrion ecology, evolution, and their applications. In: Benbow ME, Tomberlin JK, Tarone AM (eds) Carrion ecology, evolution and their applications. CRC Press, Boca Raton, pp 3-11

Birks, J.D.S. (2002). The pine marten. Mammal Society, United Kingdom. 28pp

Birks JDS (2017) Pine martens (the British natural history collection). Whittet Books Ltd, United Kingdom 216pp

Blackburn TM, Lockwood JL, Cassey P (2009) Avian invasions. The ecology and evolution of exotic birds. Oxford University Press, Oxford

Breviglieri CPB, Romero GQ (2017) Terrestrial vertebrate predators drive the structure and functioning of aquatic food webs. Ecology 98:2069-2080

Caryl FM (2008) Pine marten diet and habitat use within a managed coniferous forest. Ph.D. dissertation, University of Stirling, Stirling, Scotland

Caryl FM, Raynor R, Quine CP, Park KJ (2012) The seasonal diet of British pine marten determined from genetically identified scats. J Zool 288:252-259

Chinery, M. (1993). Insects of Britain and northern Europe. Harper Collins, 320pp

Claassens AJM, O'Gorman F (1965) The bank vole Clethrionomys glareolus Schreber: a mammal new to Ireland. Nature 205:923-924

Clevenger AP (1993) The European pine marten Martes martes in the Balearic Islands, Spain. Mammal Rev 23:65-72

Colquhoun D (2017) The reproducibility of research and the misinterpretation of p-values. R Soc Open Sci 4:171058

Cornally, A., Lawton, C., Marnell, F. (2016). A guide to the identification of Irish mammal hair, National Parks and Wildlife Service, 2016, Irish wildlife manuals, No.92

Croose, E., Birks, J.D.S., Schofield, H.W. \& O’Reilly, C. (2014). Distribution of the pine marten (Martes martes) in southern Scotland in 2013. Scottish Natural Heritage Commissioned Report No. 740

Croose E, Birks JDS, Martin J (2016) Den boxes as a tool for pine marten Martes martes conservation and population monitoring in a commercial forest in Scotland. Conservation Evidence 13:57-61

Davidson Z, Valeix M, Kesteren FV, Loveridge AJ, Hunt JE, Murindagomo F, Macdonald DW (2013) Seasonal diet and prey preference of the African lion in a waterhole-driven semi-arid savanna. PLoS One 8. https://doi.org/10.1371/journal.pone.0055182

Davies TJ, Buckley LB, Grenyer R, Gittleman JL (2011) The influence of past and present climate on the biogeography of modern mammal diversity. Philos Trans R Soc London B Biol Sci 366:2526-2535

Davison A, Birks JDS, Brookes RC, Braithwaite TC, Messenger JE (2002) On the origin of faeces: morphological versus molecular methods for surveying rare carnivores from their scats. J Zool 257: $141-143$

Day MG (1996) Identification of hair and feather remains in the gut and faeces of stoats and weasels. J Zool 148(2):201-217

Delibes M (1983) Interspecific competition and the habitat of the stone marten Martes foina (Erxleben 1777) in Europe. Acta Zool Fenn 174:229-231

Dickinson EC, Remsen JV (2013) The Howard and Moore complete checklist of the birds of the world. Aves Press

EU Habitats Directive (1992) Council Directive 92/43/EEC, European Union. Available at: http://ec.europa.eu/environment/nature/ legislation/habitatsdirective/index_en.htm

European Forestry Commission (2018). Forests, forestry and logging. European Forestry Commission, available at: https://ec.europa.eu/ eurostat/statistics-explained/pdfscache/52476.pdf 
Fairley JS (1970) Blackberries as food of pine marten. Irish Nat J 16(10): $317-318$

Forestry Commission. (2010). Forestry facts and figures 2010 - a summary of statistics about woodland and forestry. Forestry Commission, Edinburgh, available at: http://www.forestry.gov.uk/ forestry/infd-7aqf6j

Forestry Commission (2011) Forestry statistics 2011. Forestry Commission, Edinburgh Available at: http://www.forestry.gov.uk/ statistics

Forestry Commission (2017) Forestry statistics 2017. Forestry Commission, Edinburgh Available at: https://www.forestresearch. gov.uk/tools-andresources/statistics/forestry-statistics/forestrystatistics-2017/

Goszczynski J (1976) Composition of the food of martens. Acta Theriol 21:527-534

Gregory SD, Macdonald DW (2009) Prickly coexistence or blunt competition? Opuntia refugia in an invaded rodent community. Oecologia 159(1):225-236

Gurnell J, Venning T, MacCaskill B, MacCaskill D (1994) The food of pine martens ( ) in West Scotland. J Zool 234(4):680-683

Hayward MW, Kerley GIH (2005) Prey preferences of the lion (Panthera leo). J Zool 267:309-322

Hayward MW, Henschel P, O'Brien J, Hofmeyr M, Balme G et al (2006) Prey preferences of the leopard (Panthera pardus). J Zool 270:298313

Helldin JO (2000) Seasonal diet of pine marten Martes martes in southern boreal Sweden. Acta Theriol 45:409-420

Jedrzejewski W, Zalewski A, Jędrzejewska B (1993) Foraging by pine marten Martes martes in relation to food resources in Białowieża National Park, Poland. Acta Theriol 38:405-426

Kalinski A, Wawrzyniak J, Banbura M, Skwarska J, Zielinkski P, Gladalski M, Banbura J (2014) Does the threat of European pine marten (Martes martes) predation influence the height of nests built by blue tits (Cyanistes caeruleus) and great tits (Parus major)? Avian Biol Res 7(2):83-90

Klare U, Kamler JF, Macdonald DW (2011) A comparison and critique of different scat-analysis methods for determining carnivore diet. Mammal Rev 41:294-312

Langley PJW, Yalden DW (1977) The decline of the rarer carnivores in Great Britain during the nineteenth century. Mammal Rev 7:95-116

Levins R (1968) Evolution in changing environments. Princeton University Press, Princeton, $\mathrm{p} 120$

Lockie JD (1961) The food of the pine marten Martes martes in West Ross-shire, Scotland. Proc R Zool Soc London 136:187-195

Lynch AB, McCann Y (2007) The diet of the pine marten (Martes martes) in Killarney National Park. Biology \& Environment. Proc R Ir Acad 107:67-76

Marchesi P, Mermod C (1989) Regimes alimentaire de la marte (Martes martes L.) dans le Jura Suisse. Rev Suisse Zool 96:127-146

Marker LL, Muntifering JR, Dickman AJ, Mills MGL, Macdonald DW (2003) Quantifying prey preferences of free ranging Namibian cheetahs. S Afr J Wildl Res 33:45-53

Maxwell SL, Fuller RA, Brooks TM, Watson JEM (2016) Biodiversity: the ravages of guns, nets and bulldozers. Nature 536:143-146

Metz MC, Smith DW, Vucetich JA, Stahler DR, Peterson RO (2012) Seasonal patterns of predation for gray wolves in the multi-prey system of Yellowstone National Park. J Anim Ecol 81:553-563

Montgomery WI, Provan J, McCabe AM, Yalden DW (2014) Origin of British and Irish mammals: disparate post-glacial colonisation and species introductions. Quat Sci Rev 98:144-165

Ni Neachtain, R. (1998) Martes martes (an cat crainn) in the Burren, Co. Clare: an investigation of its population structure and its diet. Unpublished MSc, Trinity College, Dublin

O'Donoghue M, Boutin S, Krebs CJ, Zuleta G, Murray DL, Hofer E (1998) Functional responses of coyotes and lynx to the snowshoe hare cycle. Ecology 79:1193-1208
O’Mahony DT, Turner P, O’Reilly C (2015) Pine marten (Martes martes) abundance in an insular mountainous region using non-invasive techniques. Eur J Wildl Res 61(1):103-110

O'Meara D, Sheehy E, Turner P, O'Mahony D, Harrington A, Denman H, Lawton C, MacPherson J, O'Reilly C (2014) Non-invasive multispecies monitoring: real-time PCR detection of small mammal and squirrel prey DNA in pine marten (Martes martes) scats. Acta Theriol 59(1):111-117

O’Reilly C, Staham M, Mullins J, Turner PD, O’Mahony D (2007) Efficient species identification of pine marten (Martes martes) and red fox (Vulpes vulpes) scats using a $5^{\prime}$ nuclease real-time PCR assay. Conserv Genet 9:735-738

O'Mahoney DT, Powell C, Power J, Hanniffy R, Marnell F, Turner P, O'Reilly C (2017) Non-invasively determined multi-site variation in pine marten Martes martes density, a recovering carnivore in Europe. Eur J Wildl Res 63. https://doi.org/10.1007/s10344-0171108-3

O'Sullivan PJ (1983) The distribution of the pine marten (Martes martes) in the Republic of Ireland. Mammal Rev 13:39-44

Owen-Smith N (2008) Changing vulnerability to predation related to season and sex in an African ungulate assemblage. Oikos 117: $602-610$

Paterson, W. D, Skipper, G. (2008). The diet of pine martens (Martes martes) with reference to squirrel predation in Loch Lomond and the Trossachs National Park. University of Glasgow, Glasgow, Scotland. BSc dissertation

Pole A, Gordon IJ, Gorman ML, MacAskill M (2004) Prey selection by African wild dogs (Lycaon pictus) in southern Zimbabwe. J Zool $262: 207-215$

Popa-Lisseanu AG, Delgado-Huertas A, Forero MG, Rodríguez A, Arlettaz R, Ibáñez C, Rands S (2007) Bats' conquest of a formidable foraging niche: the myriads of nocturnally migrating songbirds. PLoS ONE 2(2):e205

Pulliainen, E. (1981). Food and feeding habits of the pine marten in Finnish Forest Lapland in winter. Pages 580-598 in J.A. Chapman \& D. Pursley (eds.) Worldwide furbearer conference Frostburg, Maryland, US

Putman RJ (2000) Diet of pine martens Martes martes L. in west Scotland. J Nat Hist 34(5):793-797

Pyke GH, Pulliam HR, Charnov EL (1977) Optimal foraging: a selective review of theory and tests. Q Rev Biol 52(2):137-154

R Core Team (2014) R: a language and environment for statistical computing. R Foundation for Statistical Computing, Vienna, Austria URL http://www.R-project.org/

Rivers MC, Beech E (2017) Sorbus aucuparia. The IUCN Red List of Threatened Species 2017: e.T61957558A112304840. https://doi. org/10.2305/IUCN.UK.2017-3.RLTS.T61957558A112304840.en

Scantlebury DM, Mills MG, Wilson RP, Wilson JW, Mills ME, Durant SM, Bennett NC, Bradford P, Marks NJ, Speakman JR (2014) Mammalian energetics. Flexible energetics of cheetah hunting strategies provide resistance against kleptoparasitism. Science 346(6205):79-81

Seabra R, Wethey DS, Santos AM, Lima FP (2015) Understanding complex biogeographic responses to climate change. Sci Rep 5:12930

Sheehy E, Lawton C (2014) Population crash in an invasive species following the recovery of a native predator: the case of the American grey squirrel and the European pine marten in Ireland. Biodivers Conserv 23:753-774

Sheehy E, O'Meara D, O'Reilly C, Smart A, Lawton C (2013) A noninvasive approach to determining pine marten abundance and predation. Eur J Wildl Res 60:223-236. https://doi.org/10.1007/ s10344-013-0771-2

Smiddy P (2018a) Dominance of invasive small mammals in the diet of the barn owl Tyto alba in county Cork, Ireland. Biol Environ: Proc R Ir Acad 118B:49-53 
Smiddy P (2018b) Diet of the common kestrel Falco tinnunculus in east Cork and west Waterford: an insight into the dynamics of invasive mammal species. Biol Environ: Proc R Ir Acad 117B:131-138

Sol D, Timmermans S, Lefebvre L (2002) Behavioural flexibility and invasion success in birds. Anim Behav 63(3):495-502

Stapp P, Polis GA (2003) Influence of pulsed resources and marine subsidies on insular rodent populations. Oikos 102(1):111-123

Stenset NE, Lutnaes PN, Bjarnadottir V, Dahle B, Fossum KH, Jigsved P, Johansen T, Neumann W, Opseth O, Ronning O, Steyaert SMJG, Zedrosser A, Brunberg S, Swenson JE (2016) Seasonal and annual variation in the diet of brown bears Ursus arctos in the boreal forest of southcentral Sweden. Wildl Biol 22(3):107-116

Taylor RJ (1984) Predation, population and community biology. Springer, Netherlands, $166 \mathrm{pp}$

Teerink, B,J (1991) Hair of West-European mammals. Cambridge University Press, 236pp

Tosh , D. (2015). Monitoring small carnivore populations using citizen scientists. European Mammal Congress. 7. Stockholm, Sweden

Tosh DG, Lusby J, Montgomery I, O'Halloran J (2008) First record of the white-toothed shrew Crocidura russula in Ireland. Mammal Rev 38: 321-326

Tosh DG, McDonald RA, Bearhop S, Lllewellyn NR, Fee S, Sharp EA (2011) Does small mammal prey guild affect the exposure of predators to anticoagulant rodenticides? Environ Pollut 159:3106-3112

Twining JP, Bernard H, Ewers RM (2017) Increasing land-use intensity reverses the relative occupancy of two quadrupedal scavengers. PLoS One 12. https://doi.org/10.1371/journal.pone.0177143

Twining J, Birks J, Martin J, Tosh D (2018) Food caching as observed through use of den boxes by European pine martens (Martes martes). Mammal Communications, 4

Vazquez DP (2006) Exploring the relationship between niche breadth and invasion success, p. 307-322 In: Conceptual ecology and invasions biology. Springer, Dordrecht

Vucetich JA, Hebblewhite M, Smith DW, Peterson RO (2011) Predicting prey population dynamics from kill rate, predation rate, and predator-prey ratios in three wolf-ungulate systems. J Anim Ecol 80:1236-1245

Walker RH, Robinson RA, Leech DI, Moss D, Barimore CJ, Blackburn JR (2017) Bird ringing and nest recording in Britain and Ireland in
2015. Ringing Migr, 31(2). https://doi.org/10.1080/03078698.2016. 1298316

Warner P, O'Sullivan P (1982) The food of the pine marten Martes martes in Co. Clare. Trans Int Congress of Game Biologists 14:323-330

Wildlife and Countryside Act (1981) Wildlife and Countryside Act, Legislation of UK Parliment. Available at: http://jncc.defra.gov.uk/ page-3614

Williamson M (1996) The varying success of invaders. Ecology 77: $1661-1666$

Wilson EE, Wolkovich EM (2011) Scavenging: how carnivores and carrion structure communities. Trends Ecol Evol 26:129-135

Wilson, D.E., Lacher, T.E., Mittermeier, R.A., Francois, T.L. (2017). Handbook of the mammals of the world, Volume 7: Rodents II. Lynx Edicions, 1008 pp.

Wilson, D.E., Mittermeier, R.A., Francois, T.L. (2018). Handbook of the mammals of the world, volume 8: insectivores, sloths and colugos. Lynx Edicions, $710 \mathrm{pp}$.

Zalewski A, Jedrzejewski W, Jedrzejewska B (1995) Pine marten home ranges, numbers and predation on vertebrates in a deciduous forest (Bialowieze National Park, Poland). Ann Zool Fenn 32:131-144

Zalewski A, Jedrzejewski W, Jedrzejewska B (2004) Mobility and home range use by pine martens (Martes martes) in a polish primeval forest. Ecoscience 11(1):113-122

Zalewski A, Jędrzejewski W (2006) Spatial organisation and dynamics of the pine marten Martes martes population in Białowieza Forest (E Poland) compared with other European woodlands. Ecography 29(1):31-43

Zhou YB, Newman C, Buesching CD, Zalewski A, Kaneko Y, Macdonald DW, Xie ZQ (2011) Diet of an opportunistically frugivorous carnivore, Martes flavigula, in subtropical forest. J Mammal 92(3):611-619

Publisher's note Springer Nature remains neutral with regard to jurisdictional claims in published maps and institutional affiliations. 